\title{
Analyzing Farm Accounting Skills Related to Financial Performance of Dairy Industry: An Evidence from Jordan
}

\author{
Ali Al-Sharafat ${ }^{1}$ \\ ${ }^{1}$ Department of Agricultural Economics and Extension, Faculty of Agriculture, Jerash University, Jerash, Jordan \\ Correspondence: Ali Al-Sharafat, Department of Agricultural Economics and Extension, Faculty of Agriculture, \\ Jerash University, P.O. Box 311, Jerash 26150, Jordan. E-mail: alijerash@gmail.com
}

Received: July 24, 2016

Accepted: September 7, $2016 \quad$ Online Published: November 15, 2016

doi:10.5539/jas.v8n12p174

URL: http://dx.doi.org/10.5539/jas.v8n12p174

\begin{abstract}
This study aimed at analyzing farm accounting skills related to the financial performance of dairy industry in Jordan. A survey procedure was adopted to measure the perspective of dairy producers about their skills in farm accounting. 13 statements related to farm accounting skills were used. The farmers skills in farm accounting were measured using mean score derived from 5 point likert-scale. The statistical population of this study consisted of all dairy producers in the country and out of them 237 dairy producers selected as statistical sample. The data were collected between March $1^{\text {st }}$ and June $30^{\text {th }}$ 2014. The results of the study concluded that dairy farmers do not possess the necessary accounting skills related to the financial performance of their activity and needed to run their enterprise in a productive way. An empirical evidence was provided about lack of accounting skills by Jordanian dairy farmers. Paying attention to farm accounting and recognition of its importance and providing suitable executive ways to its related problems will be a vital component in developing dairy industry as well as other farming activities.
\end{abstract}

Keywords: dairy industry, financial performance, farm accounting, accounting skills, Likert-scale

\section{Introduction}

The process of recording all farm resources and all farm business transactions having financial consequences on its performance in a systematic way is the job of Farm accounting (Bart, 2006). Modern agricultural procedures consider importance of record keeping, mainly accounting records, by farmers (Undutimi, 2013). Managing farm accounting affairs is a must for farmers to be successful (Yaaghubi et al., 2009). In most developing countries, including Jordan, there is a shortage in fulfillment of management accounting to managerial needs in the case of small and medium agri-business enterprises (Ahmed \& Zabri, 2012). Also, in these countries, among farm management skills, farm accounting skills often receive much less attention from decision makers, accountants and farmers (Poppe, 1991). Consequently, accounting principles were not properly applied in many agri-business activities in these countries which end in a situation in which farmers are not interested in adopting any kind of accounting measures for their activities (Poppe, 1991; Poppe \& Breembroek, 1992). On the other hand, many researchers pointed out that using accounting procedures can improve farm efficiency (Luening, 1989; Allen, 1994). Garcia et al. (1983) stated that farmers who prepared financial statements made cash flow projections better than other farmers who were not involved in accounting procedures. Streeter (1990) observed that farmers using accounting systems were with improved management systems and consequently better decision making. Furthermore, lenders for agricultural activities as well as agricultural policy makers need more accounting information that contribute to a better predicting of farm conditions (Bronstien, 1995; Crane \& Leatham, 1995; Argilés, 1998).

A conclusion can be driven that there is a need for accounting information in agri-business activities. This type of information is useful for many stakeholders in agri-business as well as the farmers themselves. Properly maintained farm accounts are very useful to the farmers regarding productivity and profitability of their farms. Sound and updated accounting records and procedures are essential to provide dependable guidelines for farmers aiding them in modifying their managerial plans in running their agri-businesses (Sharma, 2012).

In dairy industry the accounting procedures are very important in providing the necessary information for management decision making. These procedures provide the dairy farm manager with data, information and knowledge to conduct the necessary financial analysis and other diagnostic instruments, such as identifying the 
strengths and weaknesses of his business. Also, dairy farm accounting records can be used as an indicator of progress.

The aim of this study is to offer an empirical evidence on farm accounting skills related to the financial performance of dairy industry sector in Jordan through assessing the levels of adopting farm accounting techniques as a management tool by dairy producers.

\section{Dairy Industry in Jordan}

The intensive and the semi-intensive production systems are the dominant dairy production systems in Jordan. The first system found in the eastern semi-arid area of the country with an average number of 50 dairy cows per farm, and the second is dominant in the northern highlands with an average number of 5 to 20 cows per farm. Holstein is the dominant breed in the intensive production system while Shami and Akshi (local breed) are the major breeds in the semi-intensive production system. Dairy production is found all around the country. The northern province of Jordan contains most of dairy farms in the country. Ease of marketing and presence of many facilities and services related to dairy production are the main reasons that this province contains the highest percentage $(55 \%)$ of dairy farms. The middle and south provinces contains $35 \%$ and $10 \%$ respectively. Dairy farms with $11-25$ heads are the dominant category in the country. These farms constitute $47 \%$ of the whole dairy farms in Jordan. The lowest percentage (5\%) is the dairy farms with more than 50 heads (MoA, 2014).

Among Jordanian agricultural activities, dairy sector is ranked in the second place after poultry sector in terms of enterprise investment volume. Dairy farming is the main source of fresh milk in the country (Al-Sharafat, 2013). In the year 2014, total of 580 farms in the country produced around 310,000 metric tons of fresh dairy milk (MoA, 2014). Jordan is a self-sufficient country regarding fresh dairy milk. A dramatic structural change resembled by shifting to intensive production system has occurred in dairy farms in the country during the last decade. This change accompanied with economic and financial significant results related mainly to the managerial practices. Farm accounting practices were of the most important practices to be considered in this manner (Al-Faqeer, 2009). The financial performance of dairy farms will be affected due to the adoption of the intensive production system if the managerial measures, mainly the accounting measures, not taken in consideration during the change to this system of production (Alvarez et al., 2008).

\section{Materials and Methods}

\subsection{Survey and Data}

A survey procedure via structured questionnaire was used to collect primary data from the interviewed producers. A cross section survey of 237 dairy producers was conducted during the period from March $1^{\text {st }}$ toJune $30^{\text {th }} 2014$. The questionnaire was designed to obtain data related mainly to accounting skills of dairy farmers related to the financial performance of their farms as well as the socio-demographic characteristics of those farmers. To ensure reliability of the questionnaire Cronbach's alpha (CA) was computed. Reliability is the likelihood of obtaining the same results when the researcher measures the same variable more than once, or when more than one person measures the same variable. A reliable data collection instrument is that one when its measurement accurately reflects the true scores of the attribute under investigation. A data collection instrument with CA of 0.6 or higher is considered to be reliable. To measure the perspective of dairy producers about their skills in farm accounting 13 statements concerning farm accounting skills related to the financial performance of dairy farms were used. Table 1 shows the statements used to measure the perspective of dairy producers about their skills in farm accounting procedures related to the financial performance of their farms. 
Table 1. Statements used to measure accounting skills of the interviewed farmers

\begin{tabular}{ll}
\hline Statement No. & Statement Item \\
\hline 1 & You are able to record and calculate amount of initial capital in your enterprise \\
2 & You are able to record and calculate amount consumed inputs in your enterprise \\
3 & You are able to record and calculate amount conducted production in your enterprise \\
4 & You are able to record and calculate profit and loss in your enterprise \\
5 & You are able to fallow-up continuing education to improve your accounting skills \\
6 & You are effectively using financial and credit from various sources based on your accounting skills \\
7 & You are effectively managing your financial operations based on your accounting records \\
8 & You are able to create an effective accounting system for your enterprise \\
9 & You achieved performance above profitability benchmarks based on your accounting skills \\
10 & You can train your employees on accounting record keeping \\
11 & You are with high farm accounting profession \\
12 & You are with low farm accounting profession \\
13 & You need no help in accounting records in your agri-business operations \\
\hline
\end{tabular}

Source: Formulated by the researcher.

The statistical population of this study consisted of all dairy producers in the country $(\mathrm{N}=580)$ and out of them 237 producers selected as statistical sample. The survey covered the three provinces of the country (North, Middle and South). The Jordanian Department of Statistics (DoS), The Jordanian Ministry of Agriculture (MOA), The Agricultural Directorates in the country, the reports of research institutions and universities and other related sources were the main sources of secondary data.

\subsection{Sample}

Following Yamane (1967), the sample size was determined with a confidence level of $95 \%$ according to the Equation (1):

$$
\mathrm{n}=[\mathrm{N}] /\left[1+\left(\mathrm{N} \times \mathrm{e}^{2}\right)\right]
$$

Where,

$\mathrm{N}=$ Population (580); $\mathrm{n}=$ Sample size (?); $\mathrm{e}=$ Error term (0.05).

According to the above equation the dairy producers were calculated as follows:

$\mathrm{n}=[580] /\left[1+\left(580 \times 0.05^{2}\right]\right.$

$\mathrm{n}=[580] /[1+(580 \times 0.0025)]$

$\mathrm{n}=[580] /[2.45]$

$\mathrm{n}=[237]$

\subsection{Sample Distribution}

Number of the interviewed dairy farmers in each of the three provinces of the country was determined according to number of dairy farms in each province. Table 2 shows numbers and percentages of dairy farms in the country and number of the interviewed dairy farmers:

Table 2. Numbers and percentages of dairy farms in the country

\begin{tabular}{llll}
\hline Province & Number of Dairy Farms & Percentage (\%) & Number of Interviewed Farmers \\
\hline North & 319 & $(319 / 580) \times 100=55$ & $(0.55 \times 237)=130$ \\
Middle & 203 & $(203 / 580) \times 100=35$ & $(0.35 \times 237)=83$ \\
South & 58 & $(58 / 580) \times 100=10$ & $(0.10 \times 237)=24$ \\
Total & 580 & 100 & 237 \\
\hline
\end{tabular}

Note. Number of interviewed farmers was calculated by the researcher.

Source: MoA (2014). 


\subsection{Analytical Framework}

The statistical analysis in this study was based on the application of both descriptive (tables, frequencies, percentages, means, standard deviations etc.) and factors analysis of inferential statistics. The perspective of dairy producers about their skills in farm accounting related to the farm performance of their farms was measured using mean score derived from 5 point Likert-scale. Likert-scale is a an analytical tool used in making explicit decision on the attitudes attached with a particular observed phenomenon from possible factors or variables. In this study, to analyze farm accounting skills of the respondents, some farm these skills were itemized and the respondents were asked to indicate the degree of their acceptance of the statement about their accounting skills on the scale. The scale had been ranked from $1=$ very low, $2=$ low, $3=$ moderate, $4=$ high to 5 $=$ very high with decision rule of 3 .

The Likert formula is:

$$
\mathrm{Xs}=\Sigma \mathrm{Fn} / \mathrm{Nr}
$$

Where,

$\mathrm{Xs}=$ Mean score; $\sum=$ summation; $\mathrm{F}=$ frequency of each $(5,4,3,2,1)$ option; $\mathrm{n}=$ Likert numerical values (responses of the respondents); $\mathrm{Nr}=$ number of respondents to each response category (total number of respondents).

The decision rule that served as basis for acceptance or rejection of the statement that measures the perspective of dairy producers about their skills in farm accounting as indicator for their accounting abilities was determined. Decision Rule (DR) of 5-point likert-scale was calculated as follows:

$\mathrm{DR}=(5+4+3+2+1) / 5=3$

That is, if the value of the mean score of the statement is $\geq 3$, the statement is accepted, while if the value of the mean score of the statement is $<3$, the statement is rejected. Any statement about any skill with a mean score $\geq 3$ means that the skill is possessed by farmers and any statement with a mean score $<3$ means that the skill is not possessed by farmers.

\section{Results and Discussions}

\subsection{Reliability of the Data}

To examine measurement accuracy of the data and data collection instrument (its reliability), the Cronbach's Alpha (CA) of the data was computed. The computed value of the Cronbach's alpha coefficient was 0.83 . Reliability of the questionnaire was high depending on the estimated value of the Cronbach's alpha coefficient which is higher than the minimum acceptable value $(0.60)$. None of the items had to be eliminated from the questionnaire based on the reliability scores for individual items.

\subsection{Demographic Characteristics of the Respondents}

The results of the analysis on main demographic and personal characteristics of the interviewed farmers are presented in Table 3. 
Table 3. Main demographic characteristics of the respondents

\begin{tabular}{|c|c|c|}
\hline Item & Frequency (237) & Percentage (\%) \\
\hline \multicolumn{3}{|l|}{ Gender } \\
\hline Male & 230 & 97 \\
\hline Female & 7 & 3 \\
\hline Total & 237 & 100 \\
\hline \multicolumn{3}{|l|}{ Age } \\
\hline $20-30$ & 24 & 10 \\
\hline $31-40$ & 33 & 14 \\
\hline $41-50$ & 137 & 58 \\
\hline $51-60$ & 31 & 13 \\
\hline 60 and above & 12 & 5 \\
\hline Total & 237 & 100 \\
\hline \multicolumn{3}{|l|}{ Family Size } \\
\hline $2-3$ & 47 & 20 \\
\hline $4-6$ & 181 & 76 \\
\hline 7 and above & 9 & 4 \\
\hline Total & 237 & 100 \\
\hline \multicolumn{3}{|l|}{ Educational Level } \\
\hline Illiterate & 17 & 7 \\
\hline Primary & 59 & 25 \\
\hline Secondary & 121 & 51 \\
\hline Community College & 21 & 9 \\
\hline University & 12 & 5 \\
\hline Postgraduate & 7 & 3 \\
\hline Total & 237 & 100 \\
\hline \multicolumn{3}{|c|}{ Farming Experience (Years) } \\
\hline Less than 10 years & 31 & 13 \\
\hline $11-20$ & 132 & 56 \\
\hline $21-30$ & 57 & 24 \\
\hline 31 and above & 17 & 7 \\
\hline Total & 237 & 100 \\
\hline \multicolumn{3}{|c|}{ Number of Dairy Cows } \\
\hline $1-20$ & 57 & 24 \\
\hline $21-30$ & 135 & 57 \\
\hline $31-40$ & 21 & 9 \\
\hline $41-50$ & 12 & 5 \\
\hline 51 and above & 12 & 5 \\
\hline Total & 237 & 100 \\
\hline
\end{tabular}

Source: Field survey.

The results presented in Table 3 indicated that the majority (97\%) of the interviewed farmers were males and only $3 \%$ were females. This may be attributed to the fact that the dairy farming operations are difficult to be handled by females. As shown in the table, most of the interviewed farmers (72\%) were within the range of 31-50 years of productive age. This is an indication that dairy farming is dominated by male young people who are active and within the productive age group. Most of the families (76\%) were with a family size of 4-6 members. This shows that the farmers had reasonable family labor that could help in running this kind of agri-business. The result of the educational level indicated that most of the interviewed farmers $(60 \%)$ are with secondary education level and above; this suggests that dairy farming is in the hands of people who are keen to get information and use it properly including information related to farm accounting. The results further showed 
that more than half of the interviewed farmers (56\%) were with dairy farming experience of 11-20 years which is long enough that farmers do well in their enterprise. The results also revealed that more than half of the interviewed farmers (57\%) were operating their agri-business with a range of 21-30 dairy cows implying that dairy farming industry is dominated by small scale farms.

\subsection{Farm Accounting Skills of the Respondents}

Table 4 shows the mean score and the standard deviation by statement and the decision rules of accepting or rejecting of the statement as a farmer accounting skill. The mean score of the statement in the scale indicate if the farmer possesses the skill explained by the statement or not. Results, as presented in Table 4 revealed that the dairy farmers overall mean score was $2.24(<3)$, and according to the decision rule that served as basis for acceptance or rejection of the statement that measures the perspective of dairy producers about their skills in farm accounting as indicator for their accounting abilities, the farmers are not possessing the necessary farm accounting skills related to the financial performance of their farms to help them in managing their enterprise properly. This result is not consistent, to some extent, with the results obtained earlier by this study about the educational level and farming experience of the interviewed producers. The results related to educational level and farming experience of the interviewed producers suggested that dairy farming is in the hands of people who are keen to get information and use it properly since most of the interviewed farmers $(70 \%)$ completed their secondary education and above. It seems that the level of education of the interviewed producers is not aiding in acquiring the necessary farm accounting skills by those dairy producers. The same conclusion could be applied on the previously obtained result about the interviewed farmers experience in dairy farming. It seems that farmers experience in not directed, in a way or another, to acquire farm accounting skills in spite of the fact that more than half of the interviewed farmers (56\%) were with dairy farming experience of 11-20 years which is long enough that farmers do well in their enterprise.

Table 4. Mean score response of farmers on questionnaire statements and the decision rules

\begin{tabular}{lllll}
\hline Statement No. & Statement Item & Mean Score & Standard Deviation & Decision Rule \\
\hline 1 & Recording and calculating initial capital & 2.21 & 0.92 & Rejected \\
2 & Recording and calculating consumed inputs & 2.03 & 0.87 & Rejected \\
3 & Recording and calculating conducted production & 2.01 & 0.99 & Rejected \\
4 & Recording and calculating profit and loss & 1.87 & 1.03 & Rejected \\
5 & Improving accounting skills & 1.94 & 0.79 & Rejected \\
6 & Using financial and credit & 2.41 & 0.89 & Rejected \\
7 & Managing financial operations & 1.88 & 1.02 & Rejected \\
8 & Creation of an effective accounting system & 2.58 & 0.88 & Rejected \\
9 & Achieving performance above profitability benchmarks & 1.46 & 0.68 & Rejected \\
10 & Training employees on accounting record keeping & 2.12 & 1.13 & Rejected \\
11 & High farm accounting profession & 2.22 & 0.94 & Accepted \\
12 & Low farm accounting profession & 3.26 & 0.89 & Accepted \\
13 & Help needed in accounting in agri-business operations & 3.14 & 0.77 & 0.91 \\
\hline Average & & 2.24 & & \\
\hline S0urce: Comp & & \\
\hline
\end{tabular}

Source: Computed by the researcher.

\section{Conclusions}

An empirical evidence was provided about lack of accounting skills related to the financial performance of the Jordanian dairy farmers. The results of the study concludes that dairy farmers are not possessing the necessary farm accounting skills needed to run their enterprise in a productive way. Farm accounting skills which are related to the financial performance of the dairy industry can be helpful in planning dairy farm improvements and in evaluating farm enterprise, managerial control, budgeting, gains and losses and also to enable bank loans to be obtained by farmers. There is a need to develop the provision of farm accounting in a form more suitable for the use of farm manager or owner. Paying attention to farm accounting and recognition of its importance and providing suitable executive ways to its related problems will be a vital component in developing dairy industry as well as other farming activities. 


\section{References}

Ahmed, K., \& Zabri, S. M. (2012). The Uptake of Management Accounting Practices among Malaysian Firms in SMEs Sector. Paper presented at the International Conference on Technology Management, Business and Entrepreneurship, Malaysia. Retrieved from http://www.eprints.uthm.edu.my/3437

Al-Faqeer, M. Y. (2009). Survey of Frisian Dairy Farms in Dulil Area in Jordan (Master Thesis). The University of Jordan, Amman-Jordan.

Allen, R. (1994). Farm Potential: High Tech Leads the Average Farmer's Know-How. Texas Banking, 88(11), 26.

Al-Sharafat, A. (2013). Technical Efficiency of Dairy Farms: A Stochastic Frontier Application on Dairy Farms in Jordan. Journal of Agricultural Science, 5(3), 45-53. http://dx.doi.org/10.5539/jas.v5n3p45

Alvarez, A. J. del C., Solís, D., \& Pérez, J. A. (2008). Does Intensification Improve the Economic Efficiency of Dairy Farms. J. Dairy Sci., 91, 3693-3698. http://dx.doi.org/10.3168/jds.2008-1123

Argilés, J. M. (1998). Accounting Information and the Prediction of Farm Viability. Economics Working Paper 277. Barcelona: University of Pompeu Fabra.

Bart, G. (2006). Farm Accounting (1st ed.). Agromisa Foundation, Digigrafi, Wageningen, The Netherlands.

Bronstien, B. F. (1995). American Banker (p. 8). Group Seeking to Bring More Farmers into Line on Financial Reporting, November 27, 1995.

Crane, L. M., \& Leatham, D. J. (1995). External Equity Financing in Agriculture via Profit and Loss Sharing Contracts: A Proposed Financial Innovation. Agribusiness, 11(3), 223-233. http://dx.doi.org/10.1002/ 1520-6297(199505/06)11:3\%3C223::AID-AGR2720110304\%3E3.0.CO;2-X

Garcia, P., Sonka, S. T., \& Mazzacco, M. A. (1983). A Multivariate Logit Analysis of Farmers' Use of Financial Information. American Journal of Agricultural Economics, 65(1), 136-141. http://dx.doi.org/10.2307/ 1240349

Luening, R. A. (1989). Farm Records Can Improve Profitability. In United States Department of Agriculture (Ed.), Farm Management: How to Achieve Your Farm Business Goals (pp. 103-112). US. Washington: Government Printing Office.

MoA. (2014). MoA Annual Surveys. Jordanian Ministry of Agriculture.

Poppe, K. J. (1991). Information Needs and Accounting in Agriculture. Agricultural Economics Research Institute LEI, 444, 1-51.

Poppe, K. J., \& Breembroek, J. A. (1992). The Assessment of a Farm's Financial Situation. Magazine for Social Research, 7(1), 49-70.

Sharma, R. S. (2012). Accounting for Agriculture. International Journal of Recent Research and Review, 2, 62-66.

Streeter, D. H. (1990). Electronic Information Systems and Farmers Decision Making: Five Case Studies. European Review of Agricultural Economics, 19, 97-113. http://dx.doi.org/10.1093/erae/19.1.97

Undutimi, J. D. (2013). Record Keeping Among Small Farmers in Nigeria: Problems and Prospects. International Journal of Scientific Research in Education, 6(2), 214-220.

Yaaghubi, A., Chizari, M., Pezshkirad, G., \& Foeli, S. (2009). Importance of Farm Management Skills from the Viewpoint of Wheat Farmers in Tafresh Township. Journal of Agricultural Economic and Development, 17(66), 99-114.

Yamane, T. (1967). Statistics: An Introductory Analysis (2nd ed.). New York: Harper and Row.

\section{Copyrights}

Copyright for this article is retained by the author(s), with first publication rights granted to the journal.

This is an open-access article distributed under the terms and conditions of the Creative Commons Attribution license (http://creativecommons.org/licenses/by/4.0/). 